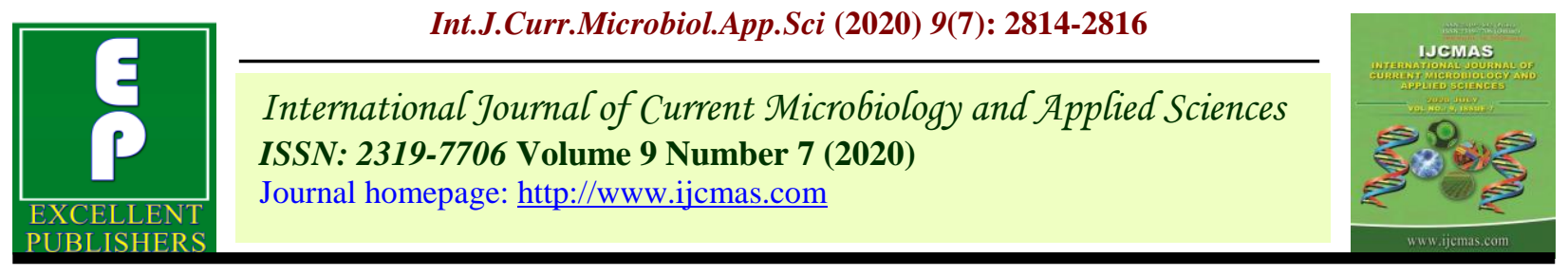

Case Study

https://doi.org/10.20546/ijcmas.2020.907.332

\title{
Management of Balanoposthitis in a Crossbred Jersey Bull
}

\author{
A. Sabarinathan ", K. Krishnakumar, J. Umamageswari, \\ N. Arunmozhi, S. Rangasamy and U. S. Kalyaan \\ Department of Animal Reproduction, Gynaecology and Obstetrics, Madras Veterinary \\ College, TANUVAS, Chennai-600 007, India \\ *Corresponding author
}

\section{A B S T R A C T}

\section{Keywords}

Balanoposthitis,

Preputial douching, Antibiotic therapy

Article Info

Accepted:

22 June 2020

Available Online:

10 July 2020
A cross bred jersey bull aged two and half years with the history of postservice bleeding from penis was presented to Large Animal Gynaecology Unit, Madras Veterinary College Teaching Hospital. Physical examination of prepuce and glans penis revealed inflammatory changes and pain whereas, testicles revealed uniform soft consistency with wrinkled scrotal skin and both the epididymis was normal. Based on clinical findings it was diagnosed as balanoposthitis and treated by preputial douching, antibiotic and anti-inflammatory drugs were administered for a course of 5 days and bull showed uneventful recovery.

\section{Introduction}

Inflammatory changes in the glans penis along with prepuce called as balanoposthitis. Balanoposthitis can be either infectious or non-infectious origin. Infectious causes include viruses such as Herpesvirus and bacteria such as Corynebacterium renale and Histophilus somni (McEntee, 2012). Trauma, lacerations, neoplasia, foreign bodies, urinary tract infection, urolithiasis, or phimosis may result in development of more severe balanoposthitis. The most common cause of balanoposthitis is trauma due to breeding injury (Birley et al., 1993). Balanoposthitis characterised externally by smaller vesicles on the body of the penis (Arjun et al., 2018). Non-infectious cause are mainly due to trauma of penis and prepuce during natural service in the young bull which are newly introduced in breeding or improper handling of artificial vagina. Balanoposthitis which is untreated will be detrimental to the reproductive health of domestic animals and it may result to infertility due to inability of mounting, intromission and ejaculation by the male (Hopkins, 2006).

\section{Materials and Methods}

A crossbred jersey bull weighing $400 \mathrm{~kg}$ was presented to Large Animal Gynaecology Unit of Madras Veterinary College Teaching Hospital, Chennai. Owner reported that bull had sanguineous discharge from the preputial sheath after animal allowed for natural service 
five days before and reluctant to do service. On general examination all the physiological parameters were within physiological limit. In the present case rectal massage of the ampulla was done to induce erection and protrusion of the penis it revealed glans penis was dark pink in colour indicated inflammatory changes. Manual exploration of the prepuce revealed pain and there were no preputial adhesions. Both the testicles were descended, uniform and soft in consistency. All the three parts of epididymis were normal. Semen sample were collected by ampullary massage in a sterile borosilicate graduated glass tube and examined for gross and individual motility, sperm abnormalities. Gross motility was graded as one with individual motility being 30 percent, numerous epithelial cast and detached heads were also observed. Based on the clinical finding the case was diagnosed as balanoposthitis.

\section{Results and Discussion}

Based on the clinical finding the case was diagnosed as balanoposthitis and was treated by douching the prepuce with $20 \mathrm{ml}$ of $10 \%$ povidone iodine reconstituted in $500 \mathrm{ml}$ of normal saline and subsequently the fluid was siphoned out. Inj.Enrofloxacin (Quintas, Intas Pharmaceuticals) @ 10mg/kg body weight and Inj.Esgipyrin-N (Zydus Animal Health Ltd,) @ 5mg/kg body weight were administered intramuscularly for three days. The bull noticed with bloody preputial discharge as described by Noakes et al., (2001).
Fig.1 Swollen preputial sheath

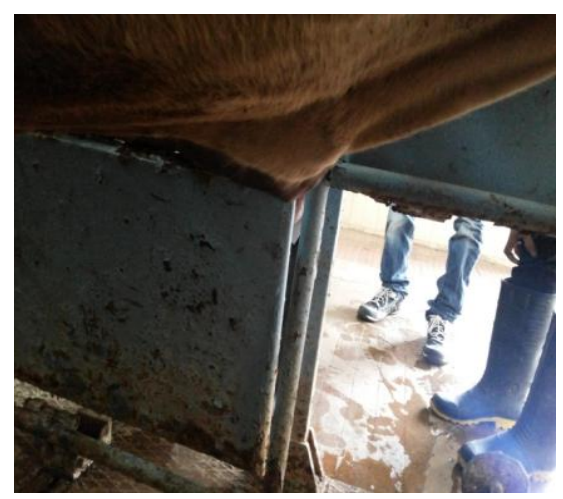

Fig.2 Inflammed glanspenis

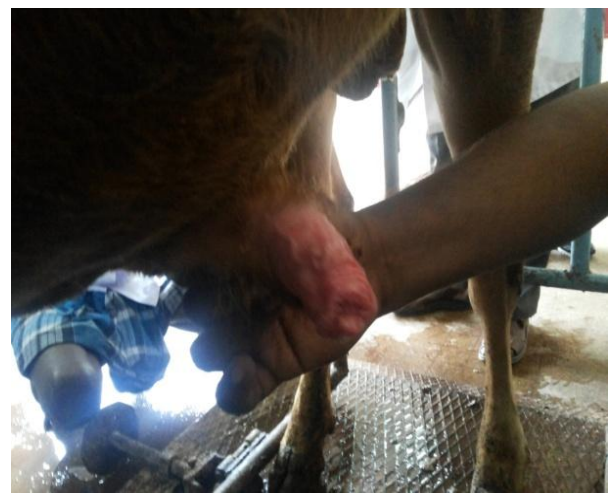

Fig.3 Preputial douching

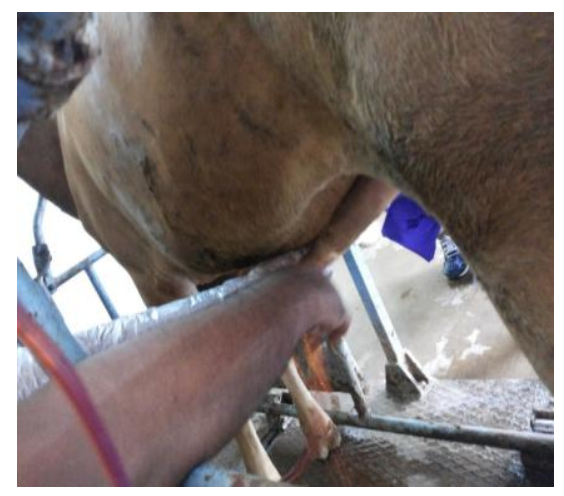

Roberts, (1971) reported that balanoposthitis due to infectious or non-infectious causes which produce pain and discomfort that affect copulation. Bull was treated with preputial douching as described by Roberts, (1971). In the present case bull was responded for the treatment of antibiotics, anti-inflammatory and preputial douching and the bull showed uneventful recovery.

The balanoposthitis in the bull can be successfully treated with administration of antibiotic, anti-inflammatory drugs combined with preputial douching with antiseptic solution.

\section{References}

Arjun, K., Sangita, M.S., Thankesawar, G and Indrapal, R. 2018. Balanoposthitis in equine and its clinical management. World Journal of Pharmaceutical Research. 7(3): 699-701.

Birley, H.D.L, Walker, M.M and Luzzi, G. 1993. Clinical features and management of recurrent balanitis association with 
recurrent washing. Genitourin Med. 69: 400-403.

Hopkins, F. M. (2006). Diseases of the reproductive system of the bull: In Current Therapy in Large Animal Theriogenology. Robert S. Young quist, Walter R. Threlfall (Editors): Second Edition, Elsevier Health Sciences. Pp 310-322

McEntee, M. (2012). Reproductive Pathology of Domestic Mammals. Elsevier. Pp
359-401

Noakes, D., Parkinson, T., England, G and Arthur, G (2001). Veterinary Reproduction and Obstetrics, 8th Edi. Saunders Ltd, United States, pp864.

Roberts, S. J. (1971). Veterinary obstetrics and genital diseases (2nd Edn). CBS Publishers and Distributors, Delhi, India.

\section{How to cite this article:}

Sabarinathan, A., K. Krishnakumar, J. Umamageswari, N. Arunmozhi, S. Rangasamy and Kalyaan, U. S. 2020. Management of Balanoposthitis in a Crossbred Jersey Bull. Int.J.Curr.Microbiol.App.Sci. 9(07): 2814-2816. doi: https://doi.org/10.20546/ijcmas.2020.907.332 